\title{
Efficient removal of Indigo dye from aqueous solution by an innovative method of emulsion liquid membrane
}

\author{
RAJA FAHAD QURESHI \\ KHADIJA QURESHI \\ ZEESHAN KHATRI
}

\author{
DOI: 10.35530/IT.069.06.1482
}

\section{REZUMAT - ABSTRACT}

\section{Eliminarea eficientă a colorantului Indigo din soluția apoasă printr-o metodă inovatoare cu membrană lichidă de emulsie}

Extracția colorantului Indigo din soluția apoasă este studiată în acestă lucrare utilizând membrane lichidă de emulsie (ELM). Emulsia de apă/ulei (W/O) a fost preparată prin amestecarea fazei apoase cu fază organică la o viteză de omogenizare ridicată. $\mathrm{H}_{2} \mathrm{SO}_{4}$ și hexanul au fost utilizați ca agent de stripare intern și, respectiv, diluant organic. Monooleatul Sorbitan, cunoscut ca Span-80, a fost utilizat ca surfactant în fază organică. Această emulsie de W/O a fost ulterior amestecată cu fază de alimentare externă care conține colorant Indigo pentru a produce emulsie dublă W/O/W. Stabilitatea membraei a fost optimizată prin experimentarea diferiților parametri de funcționare. ELM preparat în condiții optime a fost în cele din urmă utilizat pentru a îndepărta colorantul Indigo din soluția apoasă. Studiul parametrilor de proces care afectează eficiența de extracție a fost, de asemenea, efectuat. În condiții optime ale parametrilor, cum ar fi raportul de volum al emulsiei/aliementării, concentrația colorantului în alimentare, viteza de agitare și timpul de contact al celor două faze, s-a constatat că extracția colorantului Indigo este de 99\%. Prin urmare, s-a ajuns la concluzia că ELM este o tehnică atractivă și eficientă pentru eliminarea coloranților.

Cuvinte-cheie: membrane, emulsionare, stabilitate, extracție, colorant Indigo

Efficient removal of Indigo dye from aqueous solution by an innovative method of emulsion liquid membrane

Extraction of Indigo dye from aqueous solution is studied in this research using Emulsion Liquid Membrane (ELM). Water/Oil (W/O) emulsion was prepared by mixing aqueous phase with organic phase at an elevated homogenizing speed. $\mathrm{H}_{2} \mathrm{SO}_{4}$ and Hexane were used as internal stripping agent and organic diluent respectively. Monooleate Sorbitan commonly known as Span-80 was used as surfactant in organic phase. This W/O emulsion was later mixed with external feed phase containing Indigo dye to make W/O/W double emulsion. Stability of the membrane was optimized by experimenting different operating parameters. The ELM prepared under the optimum conditions was finally used to remove Indigo dye from aqueous solution. The parametric study of the process parameters affecting the extraction efficiency was also performed. Under optimum conditions of parameters like volume ratio of emulsion/feed, dye concentration in feed, stirring speed and contact time of two phases, the extraction of Indigo dye was found to be $99 \%$. Therefore, ELM was found to be an attractive and effective technique for the removal of dyes.

Keywords: membranes, emulsification, stability, extraction, Indigo dye

\section{INTRODUCTION}

Discharge of a huge quantity of wastewater containing toxic organic solutes is a common practice of many industries now-a-days. Amongst these, textile industry is a major contributor of promoting environmental degradation in terms of water pollution globally. Textile wastewater is known to contain strong color, high $\mathrm{pH}$, temperature, $\mathrm{COD}$ and low biodegradability [1]. This effluent may contain different hazardous chemicals, dyes and pigments. Not only the large scale industries, but the small scale industries commonly called as cottage industries of textile also indulging a remarkable negative impact on environment. Ajrak industry is one example of a classical cottage industry of textile usually exist in India and Pakistan. This small scaled industry usually operated in villages; produces "Ajrak"; a piece of dyed cloth and printed with unique patterns. Among different colors being applied on Ajrak, blue is one of the prominent color usually achieved with Indigo dyes. Traditionally, this Indigo dye was of natural origin but its increasing demand and high cost of natural dyes has replaced it with synthetic Indigo dyes which are highly toxic, carcinogenic and mutagenic [2]. Ajrak industry also adopts the similar practice of disposing the untreated wastewater directly into surface water. This practice of discharging the effluent containing lethal contamination into water streams is not only destructive for aquatic ecosystem but also toxic for human beings. In a report, synthetic indigo is thought to be contaminated in water streams posing several threats into the marine species as it can be oxidized into "isatin" then be hydrolyzed to "Anthranilic Acid"; a hazardous compound that is toxic to Aquatic life [3]. ELM is one promising technique for the treatment of various industrial wastes since its invention. The extraction process by ELM was introduced for the first time by N. N. Li [4]. This technique has many 
advantages over the other treatments methods which has made this process more significant and highly prospective. Many studies have been carried out for the extraction of different species from water by using ELM technique like heavy metals [5, 6], precious metals [7], phenol [8], organic acids [9-10], aniline [11], bioactive material [12]. Removal of different classes of dyes through ELM process with extraction efficiency above $99 \%$ is reported in different studies. An efficient removal of acid dyes [13-14], Anionic dyes [15-16], cationic dyes [17-18], reactive dyes [19], crystal violet and methylene blue dyes [20] is reported in literature. To the best of our knowledge, no work has been done on the extraction of Indigo dyes by ELM process. The present study is aimed to remove Indigo dye from the aqueous solution by using ELM technology considered as one highly hazardous contaminant present in the effluent of "Ajrak" Cottage industry.

\section{EXPERIMENTAL}

\section{Material}

Sorbitanmonooleate commercially known as Span-80 and sulfuric acid ( $97 \%$ purity) used in this study was obtained from Merck. Hexane fraction from petroleum used in this research was also a laboratory reagent grade manufactured by Fisher Scientific (UK). Indigo dye was courteously collected from the local textile cottage industry of Ajrak. ULTRA-Turax T-25 Homogenizer was used for the emulsification of aqueous internal phase and organic phase, whereas the mixing of W/O emulsion with external phase was achieved with ADVANTEC MIDGET mechanical stirrer attached with a four bladed propeller type shaft. UV-1800 SHIMADZU UV-Spectrophotometer was used for measuring the absorption intensity of the Indigo dye before and after the treatment (figure1).

\section{Procedure}

\section{Stability analysis}

Before emulsification of the W/O emulsion, both the aqueous and organic phases were separately prepared. Aqueous phase was prepared by dissolving an appropriate amount of $\mathrm{H}_{2} \mathrm{SO}_{4}$ in distilled water to make solutions of different molar strengths. Measured quantities of Hexane were mixed with Span-80 to make the organic phase. Hexane was used as organic diluent whereas Span-80 assurfactant. The solution was stirred and heated on WISE-STIR magnetic stirrer for 10 minutes at $30^{\circ} \mathrm{C}$ for a fixed stirring velocity of $700 \mathrm{rpm}$. To determine the emulsion stability, both these phases were initially mixed to make W/O emulsion under the varying speeds of ULTRA-Turrax T-25 Homogenizer from 3,000 to $10,000 \mathrm{rpm}$ and then the prepared emulsion was filled in scaled test tubes. The test tubes were placed in test tube holder and kept for 24-hours at normal room temperature $\left(25-30^{\circ} \mathrm{C}\right)$. After 24 -hours, the phase separation ratio of the aqueous and oil was calculated using the following expression:

$$
\text { Stability } \%=\frac{V t-V w}{V t} \times 100
$$

Where $V t$ is the total volume of the emulsion in the test tube, $V w$ - the separated volume of the aqueous phase in the test tube after 24 hours.

\section{Extraction of Indigo dye}

External feed phase was prepared by dissolving different quantities of Indigo dye in distilled water to make required dye concentrations. The prepared external phase contained in a PYREX glass beaker was placed under shaft of ADVANTEC MIDGET mechanical stirrer while pouring the W/O emulsion slowly into the beaker. The mechanical stirrer was rotated at different mixing speeds resulting in a Water/Oil/Water (W/O/W) double emulsion. After some definite time, contains of the beaker were transferred into a separating funnel and allowed for phase separation. The treated water was finally collected in a fresh beaker from the bottom of the funnel while the remainder in the funnel was collected separately for reuse of membrane after demulsification process.

\section{RESULTS AND DISCUSSION}

\section{Parametric study}

Parametric study on the behavior of formulated ELM with respect to stability and extraction efficiency was conducted by using conventional single factor design method. According to this method, all the parameters were initially set on one constant value except one parameter which was varied. Later this parameter was fixed at an optimum level varying the other parameter. This process continued till all the working parameters were individually optimized.



Fig. 1. Extraction process of Indigo dye by ELM process: $a$ - preparation of W/O emulsion; $b$ - stable emulsion; $c$ - mixing of dye phase with W/O emulsion; $d$ - separation of phases in separating funnel; $e$-dye extracted from aqueous solution

Effects of operational parameters on membrane stability

\section{Effect of aqueous phase concentration}

Concentration of the stripping agent in aqueous phase plays very vital role in the stability analysis of any ELM system. Experiments were conducted to determine the optimal concentration of aqueous phase to 
formulate an ELM with required stability. Figure 2 shows the effect of concentration of $\mathrm{H}_{2} \mathrm{SO}_{4}$ on the stability of ELM. Figure shows that the stability of emulsion is maximum at the lowest molar concentration of $\mathrm{H}_{2} \mathrm{SO}_{4}$. With the increase in concentration of $\mathrm{H}_{2} \mathrm{SO}_{4}$, the stability of the ELM is slightly decreased. This change in behavior can be attributed due to the partial hydrolysis of the surfactant which is catalyzed by protons. Surfactant present in the organic phase possesses some deteriorating properties also which results in the rupture of membrane consequently decreasing the stability.

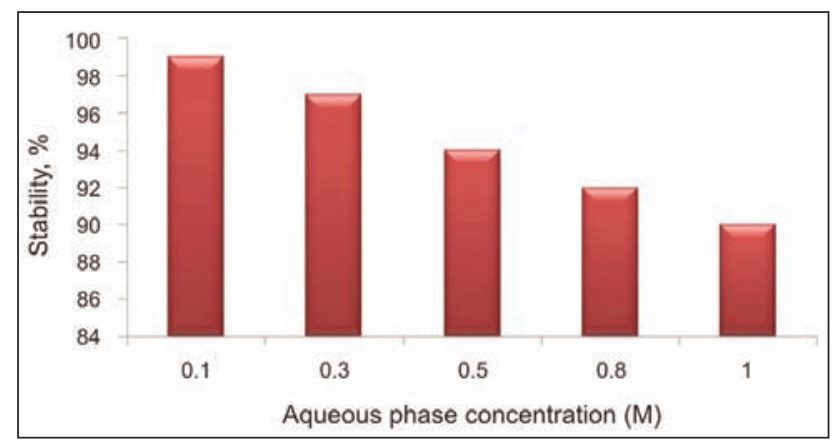

Fig. 2. Effect of aqueous phase concentration on stability of ELM

\section{Effect of surfactant concentration}

Surfactant acts as an emulsifier in any ELM system that reduces the interfacial tension between the phases of emulsion. In this study Sorbitanmonooleate, commonly known as Span-80, is used as non-ionic surfactant. The effect of Span-80 as surfactant on the stability of required emulsion is presented in figure 3 . It is observed from the figure that stability is not good below $5 \%(\mathrm{w} / \mathrm{v})$ of surfactant. This is due to the insufficient quantity of surfactant for making an adequate layer for surrounding all the aqueous phase. The maximum stability i.e. $100 \%$ is achieved at surfactant concentration of $5 \%$, whereas the further increase in the concentration showed no any significant change and stability remained nearly constant.

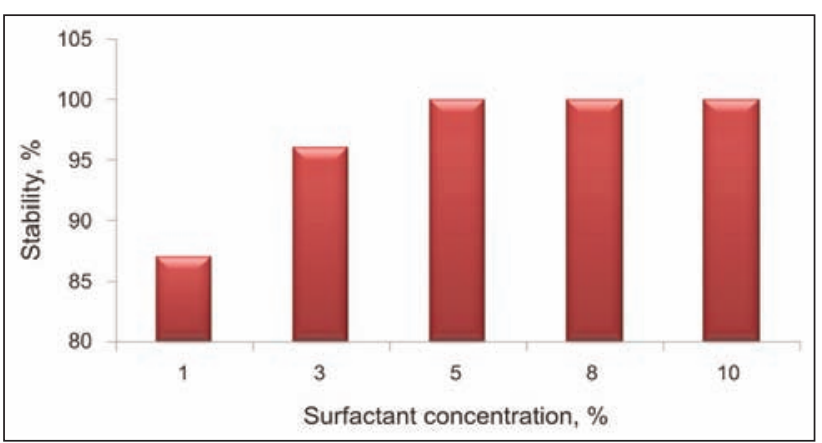

Fig. 3. Effect of surfactant concentration on stability of ELM

\section{Effect of volume ratio of organic/aqueous phase}

Figure 4 shows the effect of the volume ratio of the organic/aqueous phase on the stability of the required emulsion. From the figure it can be observed that the best maximum stability was achieved at the ratio of 1:2 (organic:aqueous). This can be explained by the fact that an increase in aqueous phase volume fraction shifts the internal drop size distribution toward larger sizes and causes an increase in the emulsion viscosity [21] and it is well known that high viscosity is generally favorable for the stability of the emulsion.

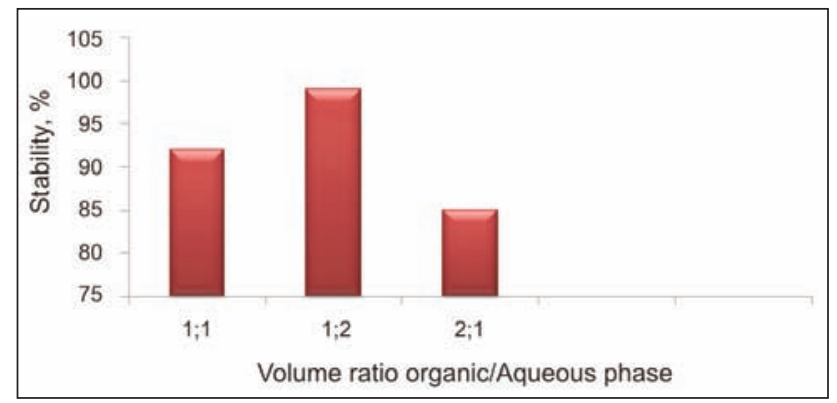

Fig. 4. Effect of volume ratio (organic/aqueous) on stability of ELM

\section{Effect of emulsification time}

Experiments were conducted to determine the effect of emulsification time on the stability of required emulsion. This effect is determinant from figure 5. It can be observed from the figure that stability was not good at lower emulsification time up to 5 minutes. Stability increased gradually and maximum stability was achieved at 10 minutes of emulsification time. Further increase above 10 minutes showed the reduction in membrane stability. This effect can be elucidated by understanding the phenomenon that the quantity of the emulsion droplets formed below the time of 5 minutes was very low in quantity while their size was relatively high. This behavior supported the property of coalescences to form bigger droplets thus destabilizing the emulsion. In contrast, for increased emulsification time above 10 minutes, the internal shearing for longer duration generate a high number of smaller droplets which increases the risk of emulsion breakage due to their high collision frequency.

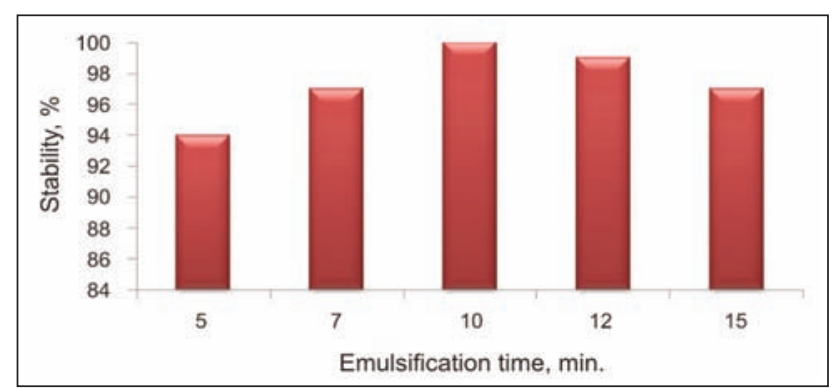

Fig. 5. Effect of emulsification time on stability of ELM

\section{Effects of operational parameters on the extraction of Indigo dye}

\section{Effect of volume ratio of emulsion/feed phase}

The extraction efficiency of the ELM system depends on different factors. Experiments were conducted to analyze these effects. Before analyzing the extraction 
efficiency, the stable membrane was developed according to optimized values of parameters previously observed. These optimum values include $0.1 \mathrm{M}$ concentration of $\mathrm{H}_{2} \mathrm{SO}_{4}$ in aqueous phase, $5 \%$ Span-80 as concentration of surfactant, $8000 \mathrm{rpm}$ emulsification speed and 10 minutes homogenization time.

For optimum extraction, volume ratio of emulsion to feed phase was experimented and analyzed. From figure 6 we can conclude the result by observing that the maximum extraction efficiency is achieved at the ratio of 1:5. Further increase in the ratio decreases the efficiency. This can be explained by the phenomena of swelling (water passage from external feed phase to internal aqueous phase), thereby decreasing the membrane film thickness resulting the emulsion become unstable, which intern decreasing the extraction of target solute.

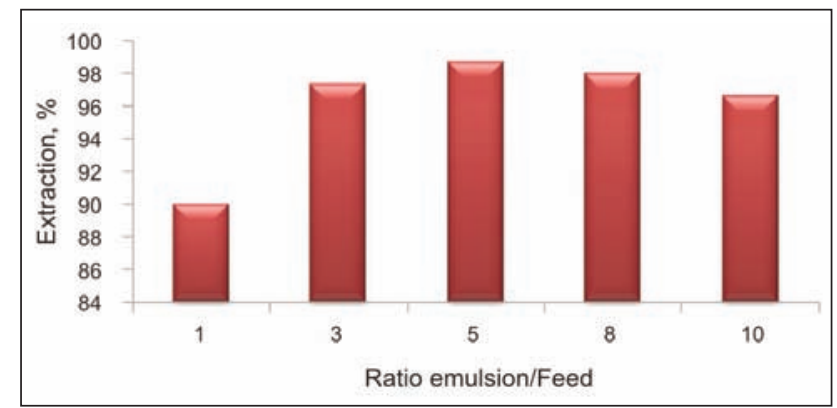

Fig. 6. Effect of volume ratio (emulsion/feed) on extraction of Indigo dye

\section{Effect of dye concentration in feed phase}

In separation processes, the quantity of the target is also one important factor to be considered. In this study, the effect of Indigo dye concentration in external feed phase was also observed by varying its concentration. Figure 7 shows that the maximum extraction efficiency is achieved at dye concentration of $50 \mathrm{ppm}$. For concentrations above $50 \mathrm{ppm}$, the extraction yield decrease which is due to the saturation of internal phase droplets by the target dye particles.

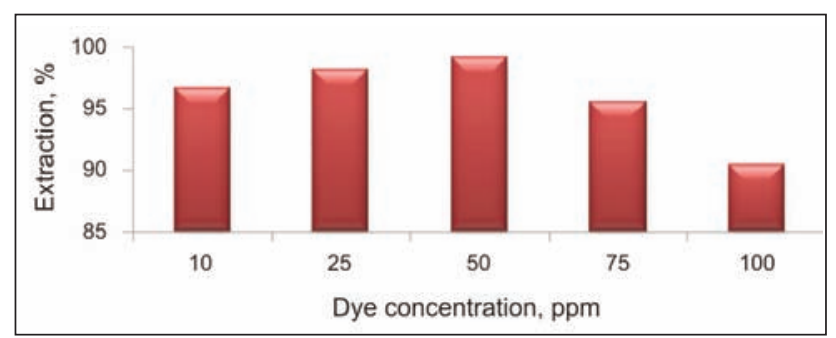

Fig. 7. Effect of dye concentration in feed on extraction of Indigo dye

\section{Effect of stirring speed for mixing the emulsion and feed phases}

The stirring speed plays a major role in the rate of extraction of any solute through emulsion liquid membrane. The effect of stirring/mixing speed in this study was also observed and produced in figure 9. From the graph in figure 8 , it is observed that increasing the speed from 50 to $100 \mathrm{rpm}$, an increase in extraction efficiency is noticed. However, further increase in speed above 100 rpm gradually decreases the extraction efficiency. This can be attributed as lower stirring speed below $100 \mathrm{rpm}$ is not adequate to form smaller sized emulsion droplets in maximum number for trapping the maximum quantity of dye particles. At optimal speed of 100 rpm, a good number of smaller sized emulsion droplets are formed leading to more surface area provided for better mass transfer. Further increase in speed increases



Fig. 8. Images showing difference in absorbance curves at same wavelength (left) absorbance of dye solution at $670 \mathrm{~nm}$ before ELM treatment $1.754 \%$ (right) absorbance of dye solution at $670 \mathrm{~nm}$ after ELM treatment $0.025 \%$ 


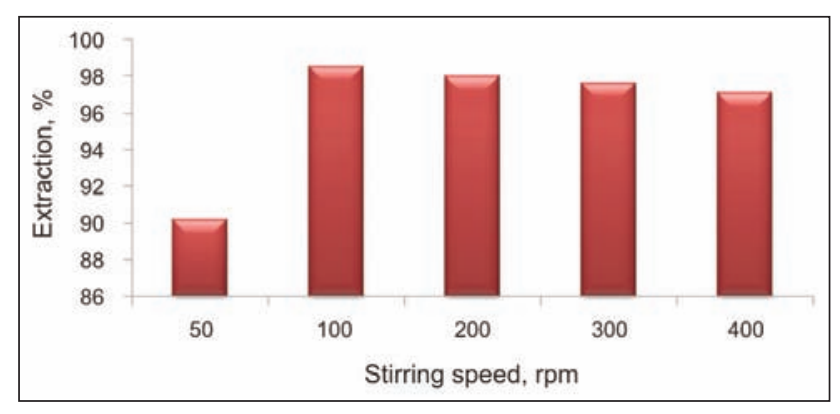

Fig. 9. Effect of stirring speed on extraction of Indigo dye

the shearing force on the system, thus by reducing the stability of membrane causing the emulsion rupture and diminishing the extraction efficiency.

\section{Effect of contact time}

Experiments were conducted to determine the effect of contact time of two phases (membrane and feed phases) on the extraction of Indigo dye. From the figure 10, it is noticed that the dye extraction increased with the increase of contact time from 3-5 min. This increase is evident up to this level, while as the further increase in contact time from 5-15 min results in a smaller reduction in percent extraction of Indigo dye. This indicates the similar behavior as previously discussed with stirring speed, i.e. increase in time of contact or mixing of emulsion and feed phase will also increase the time to resist the sheer force developed due to agitation by the system. This will adversely affect the emulsion stability resulting in rupture of



Fig. 10. Effect of contact time on extraction of Indigo dye

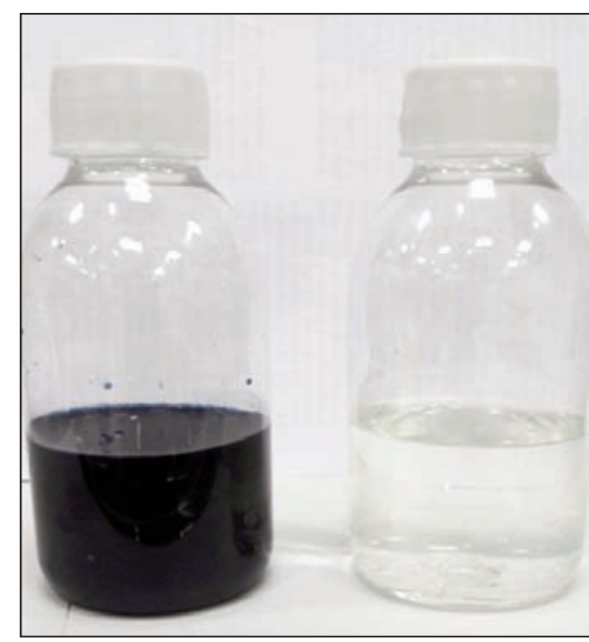

Fig. 11. Aqueous dye solution containing Indigo dye (left), water treated with ELM Process (right)

liquid emulsion membrane leading to outflow of extracted dye back into the external phase, thereby decreasing the extraction efficiency.

\section{CONCLUSION}

A study was carried out to remove an Indigo dye from aqueous solutions through ELM technique. Parameters affecting the stability of the emulsion were studied and a stable emulsion was formulated under optimum parameters for subsequent extraction process for Indigo dye. These optimum parameters include $0.1 \mathrm{M} \mathrm{H}_{2} \mathrm{SO}_{4}$ as concentration of aqueous phase, $5 \%$ as concentration of surfactant Span-80, 1:2 as volume ratio of organic to aqueous phase, $8000 \mathrm{rpm}$ emulsification speed and $10 \mathrm{~min}$ as emulsification time. Different operating parameters affecting the extraction yield of the ELM system were also optimized to obtain maximum extraction efficiency. It was concluded that under optimum conditions of parameters, $99 \%$ extraction of Indigo dye from aqueous solution can be attained. Therefore, this study concludes that ELM technology has potential to remove Indigo dye from the textile cottage industry of Ajrak much efficiently.

\section{BIBLIOGRAPHY}

[1] Scarlat, R., Floarea, P., Marius, I. Integrated systems of monitoring and controlling waste water quality, In: Industria Textila, 2013, vol. 64, no.1, pp. 140-145.

[2] Buscio, V., Crespi, M., Gutiérrez-Bouzán, C. Sustainable dyeing of denim using indigo dye recovered with polyvinylidene difluoride ultrafiltration membranes, In: Journal of Cleaner Production, 2015, vol. 91, no.3, pp. $201-207$.

[3] Zhu, X., Bao, L., Wei, Y., Ma, J., Kong, Y. Removal of toxic indigo blue with integrated biomaterials of sodium carboxymethyl cellulose and chitosan, In: International Journal of Biological Macromolecules, 2016, vol. 91, no.1, pp. 409-415.

[4] Lee, N. ed., Google Patents, Separating hydrocarbons with liquid membranes, 1968.

[5] Uddin, M. S., Kathiresan, M. Extraction of metal ions by emulsion liquid membrane using bi-functional surfactant: equilibrium and kinetic studies, In: Separation and Purification Technology, 2000, vol. 19, no.2, pp. 3-9.

[6] Zaheri, P., Davarkhah, R. Rapid removal of uranium from aqueous solution by emulsion liquid membrane containing thenoyltrifluoroacetone, In: Journal of Environmental Chemical Engineering, 2017, vol. 5, no. 4, pp. 4064-4068. 
[7] Kargari, A., Kaghazchi, T., Soleimani, M. Role of emulsifier in the extraction of gold (III) ions from aqueous solutions using the emulsion liquid membrane technique, In: Desalination, 2004, vol. 162, pp. 237-247.

[8] Messikh, N., Bousba, S., Bougdah, N. The use of a multilayer perceptron (MLP) for modelling the phenol removal by emulsion liquid membrane, In: Journal of Environmental Chemical Engineering, 2017, vol. 5, pp. 3483-3489.

[9] Itoh, H., Thien, M. P., Hatton, T. A. Water transport mechanism in liquid emulsion membrane process for the separation of amino acids, In: Journal of Membrane Science, 1990, vol. 51, pp. 309-322.

[10] Hong, S., Yang, J. Process development of amino acid concentration by a liquid emulsion membrane technique, In: Journal of Membrane Science, 1994, vol. 86, pp. 181-192.

[11] Datta, S., Bhattacharya, P. K., Verma, N. Removal of aniline from aqueous solution in a mixed flow reactor using emulsion liquid membrane, In: Journal of Membrane Science, 2003, vol. 226, pp. 185-201.

[12] Thien, M. P., Hatton, T. A. Liquid emulsion membranes and their applications in biochemical processing, In: Separation Science and Technology, 1988, vol. 23, pp. 819-853.

[13] Bahloul, L., Ismail, F., Samar, M. E.-H., Meradi, H. Removal of AY99 from an aqueous solution using an emulsified liquid membrane. Application of Plackett-burman Design, In: Energy Procedia, 2014, vol. 50, no. 3, pp. $1008-1016$.

[14] Bahloul, L., Meriem, D., Bendebane, F., Meradi, H., Ismail, F. Effects of parameters on the extraction yield of Acid Orange 10 by ELM from an aqueous solution. Application of Plackett-Burman Design, In: International Journal of Engineering and Applied Sciences, 2015, vol. 2, no. 7, pp. 74-78.

[15] Dâas, A., Hamdaoui, O. Extraction of anionic dye from aqueous solutions by emulsion liquid membrane, In: Journal of Hazardous Materials, 2010, vol. 178, pp. 973-981.

[16] Bahloul, L., Bendebane, F., Djenouhat, M., Meradi, H., Effects and optimization of operating parameters of anionic dye extraction from an aqueous solution using an emulsified liquid membrane: Application of designs of experiments, In: Journal of the Taiwan Institute of Chemical Engineers, 2016, vol. 59, pp. 26-32.

[17] Djenouhat, M., Hamdaoui, O., Chiha, M. Ultrasonication-assisted preparation of water-in-oil emulsions and application to the removal of cationic dyes from water by emulsion liquid membrane: Part 2. Permeation and stripping, In: Separation and Purification Technology, 2008, vol. 63, pp. 231-238.

[18] Bahloul, L., Ismail, F. Extraction and desextraction of a cationic dye using an Emulsified Liquid Membrane in an Aqueous Solution, In: Energy Procedia, 2013, vol. 36, pp. 1232-1240.

[19] Othman, N., Zailani, S. N., Mili, N. Recovery of synthetic dye from simulated wastewater using emulsion liquid membrane process containing tri-dodecyl amine as a mobile carrier, In: Journal of Hazardous Materials, 2011, vol. 198, pp. 103-112.

[20] Das, C., Rungta, M., Arya, G. Removal of dyes and their mixtures from aqueous solution using liquid emulsion membrane, In: Journal of Hazardous Materials, 2008, vol. 159, no. 3, pp. 365-371.

[21] Duanping, Xu., Changjian, Gu. Adsorption and removal of acid red $3 R$ from aqueous solution using flocculent Humic acid isolated from lignnite, In: Procedia Environmental Sciences, 2013, vol. 18, pp. 127-134.



